\title{
Follicular T-Cell Lymphoma
}

National Cancer Institute

\section{Source}

National Cancer Institute. Follicular T-Cell Lymphoma. NCI Thesaurus. Code C80375.

A lymph node-based peripheral T-cell lymphoma of T-follicular helper (TFH) cells, with a predominantly follicular growth pattern. It lacks characteristic features of angioimmunoblastic T-cell lymphoma such as proliferation of high endothelial venules or extrafollicular follicular dendritic cells. (WHO 2017) 